\title{
Microbial Communities in the Fynbos Region of South Africa: What Happens during Woody Alien Plant Invasions
}

\author{
Karin Jacobs ${ }^{1, *(\mathbb{D}}$, Tersia Conradie ${ }^{1}(\mathbb{D})$ and Shayne Jacobs ${ }^{2}$ \\ 1 Department of Microbiology, Stellenbosch University, Private Bag X1, Matieland, \\ Stellenbosch 7600, South Africa; tcon@sun.ac.za \\ 2 Department of Conservation Ecology and Entomology, Stellenbosch University, Private Bag X1, Matieland, \\ Stellenbosch 7600, South Africa; sjacobs@sun.ac.za \\ * Correspondence: kj@sun.ac.za; Tel.: +27-21-808-5806
}

Received: 11 May 2020; Accepted: 15 June 2020; Published: 22 June 2020

\begin{abstract}
The Cape Floristic Region (CFR) is globally known for its plant biodiversity, and its flora is commonly referred to as fynbos. At the same time, this area is under severe pressure from urbanization, agricultural expansion and the threat of invasive alien plants. Acacia, Eucalyptus and Pinus are the common invasive alien plants found across the biome and considerable time, effort and resources are put into the removal of invasive alien plants and the rehabilitation of native vegetation. Several studies have shown that invasion not only affects the composition of plant species, but also has a profound effect on the soil chemistry and microbial populations. Over the last few years, a number of studies have shown that the microbial populations of the CFR are unique to the area, and harbour many endemic species. The extent of the role they play in the invasion process is, however, still unclear. This review aims to provide an insight into the current knowledge on the different microbial populations from this system, and speculate what their role might be during invasion. More importantly, it places a spotlight on the lack of information about this process.
\end{abstract}

Keywords: fynbos; soil; Acacia spp.; Eucalyptus spp.; oligotrophic; microbial

\section{Introduction (to the Fynbos Biome)}

The Cape Floristic Region (CFR), also referred to as the core Cape Floristic subregion, at the southern end of the African continent is considered to be one of the most diverse biomes in the world [1-3], with around 9300 described plant species, of which $67 \%$ are endemic to the region [3-9] (Figure 1). According to the Cape Town Biodiversity report [9], it is one of 35 global plant biodiversity hotspots. Reflected in this diversity is that of the microbial communities [10-16]. The CFR is characterised by different vegetation types, but can broadly be summarised as Sand fynbos, Alluvium fynbos, Granite fynbos, Sandstone fynbos, Shale fynbos, Renosterveld, Cape flats Dune strandveld, Cape Seashore Vegetation, and the Southern Afro-temperate Forest [6]. The word fynbos refers to the vegetation and originates from the Dutch word meaning "fine bush". Despite the fact that this area is of great ecological value, it also has a major metropole (Cape Town City), which leaves a significant footprint (Figure 1). From their biodiversity report, the City of Cape Town has shown that the different vegetation types within the city limits range from poorly protected to well protected, although more than half are critically endangered [9]. 


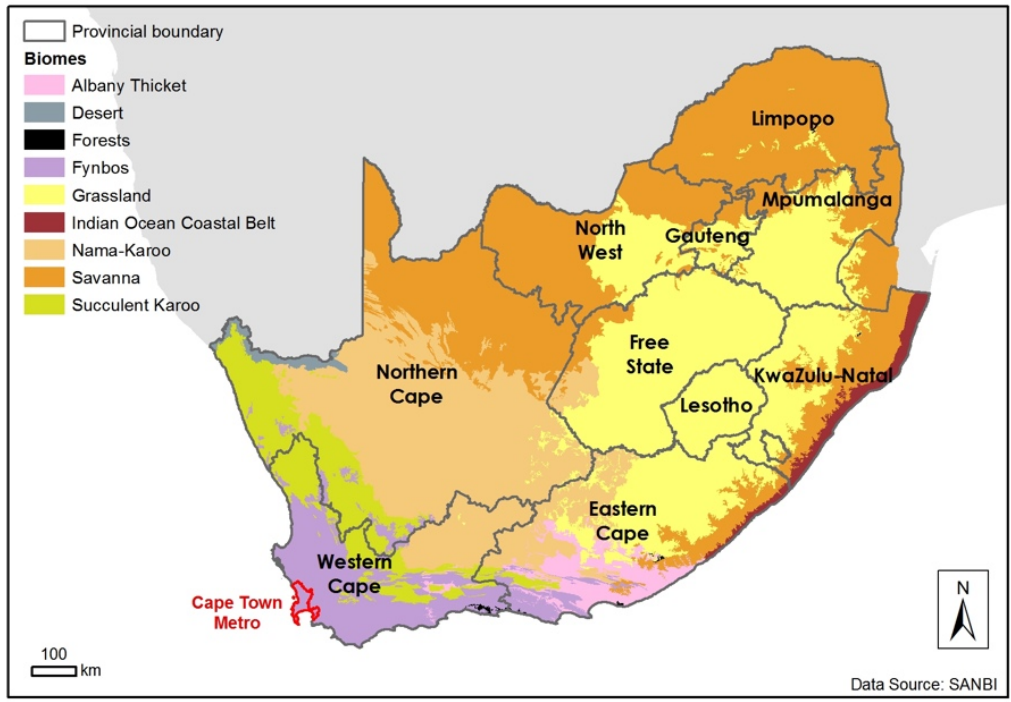

Figure 1. Different biomes in South Africa. The Cape Floristic Region (CFR) or fynbos is indicated by the purple areas in the Western part of the country [17]. (Reproduced with permission from [9]).

The loss of fynbos vegetation is mainly due to land use practices that include agriculture and forestry, the expansion of urban areas, and the displacement of native plants through alien plant invasion $[5,8]$. There is a close link between the above ground and below ground communities. This loss of diversity in the above ground plants are mimicked in the microbial community changes [18]. The fact that many of the vegetation types are critically endangered is troubling and 49 plant species are already confirmed to be extinct [9], and many more are close to extinction within the conservation area (Figure 2). Based on limited previous studies, one can assume that the same is true for the microbial communities, but in the absence of surveys, this can only be estimated.

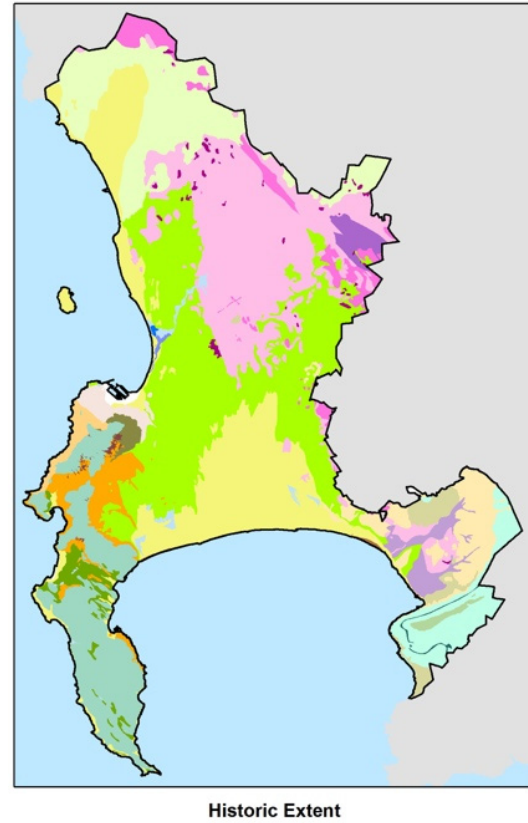

Historic Extent

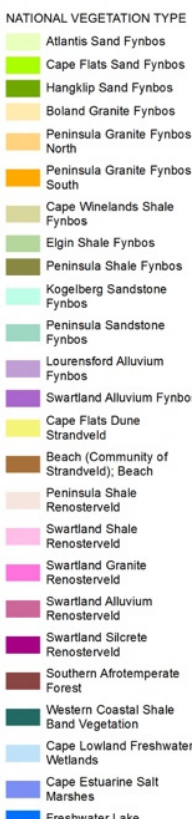

- Mreshwater Lake

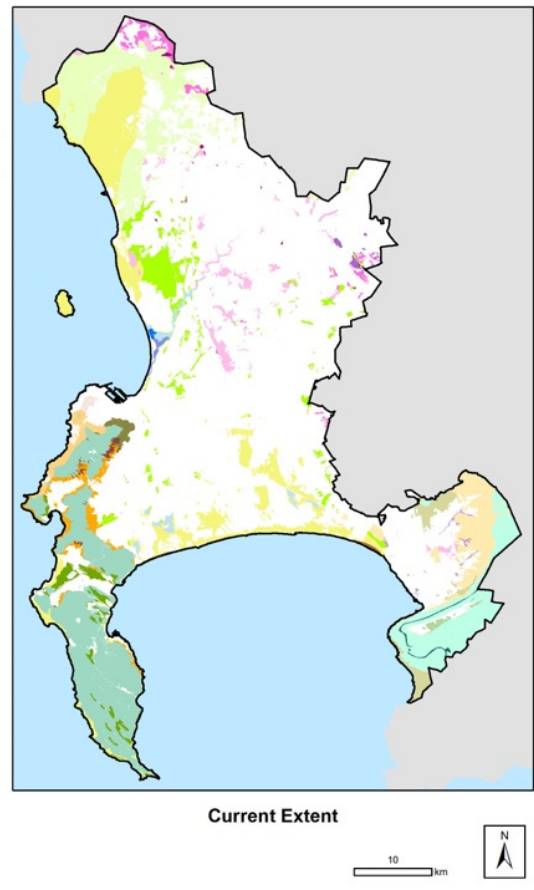

Figure 2. Different vegetation types within the fynbos biome showing the historical distribution and remaining patches on the left in 2017 [19]. (Reproduced with permission from [9]). 


\section{Plant-Soil-Microbial Interactions}

The high plant diversity is likely the result of a relatively stable climate during the Cenozoic period after rapid changes in the Miocene, which resulted in higher plant diversity [20,21]. This is similar to other Mediterranean ecosystems, where the high diversity in plant species is linked to greater environmental stability [21]. A sixth of all plant species in South Africa is found in the fynbos biome, which covers only $4-6 \%$ of the land area [9]. The fynbos biome is mostly known for the iconic Protea spp., and $90 \%$ of this genus is endemic to the fynbos biome (Figure 3). This is also true for the Ericaceae, and the majority of the diversity in this group can be found in the fynbos biome [22]. Fynbos soils are naturally acidic, and low in nitrogen $(\mathrm{N})$ and phosphorus $(\mathrm{P})$ [23]. Plants, together with a suite of microorganisms, are adapted to this oligotrophic environment through increased plant biomass and biochemical partitioning to roots, cluster roots, exudation of organic acids and phosphatase enzymes for phosphorous acquisition [24,25]. In a semiarid Mediterranean ecosystem, microbial communities were found to be resilient, although they were subjected to strong seasonal shifts and prolonged droughts [26]. This could potentially be true for the fynbos biome, although this has not been tested.

A complex ecosystem of bacteria, fungi, protists and animals inhabits the soil [27], and mostly exhibit positive ecological interactions that promote plant growth. In order to make nutrients such as nitrogen and phosphorus, available to plants, both plants and microorganisms excrete enzymes to cleave nitrogen and phosphorus from organic forms [28,29]. Nitrogen limitations of soils are also overcome by the fixing of atmospheric nitrogen by various bacterial taxa associated with leguminous plants, as well as a number of free-living bacteria [30]. The interaction between plant roots, soil and microorganisms is most intense in the rhizosphere and plant exudates play a significant role in structuring the microbial communities [31]. Within the rhizosphere, there are increased concentrations of phosphatases as well as acidification, enhancing the uptake for both nitrogen and phosphorus. Phosphorus uptake is also enhanced by the activity of mycorrhizae in the root system. Microorganisms in the rhizosphere react with multiple metabolites released by plant roots, where they have mutualistic relationships that favor plant growth, change nutrient dynamics, and also alter the plants vulnerability to heavy metals, abiotic stress, and diseases [32]. In return, plants release compounds in the form of root exudates, creating a unique environment in the rhizosphere and providing microbes with essential components such as sugars, amino acids, flavonoids, aliphatic acids, proteins and fatty acids $[28,33]$. In some cases, plants can also use their exudates to suppress the growth of microorganisms to reduce the competition for nutrients in low concentrations [31]. Although plants can exert a strong selection pressure on the communities in the rhizosphere, ultimately, the inherent soil composition and nutrient availability is critical to the stability of the system [34]. Spatial variation of these nutrients, as well as soil $\mathrm{pH}$, is important in determining the spatial distribution of fynbos plant species [35]. 


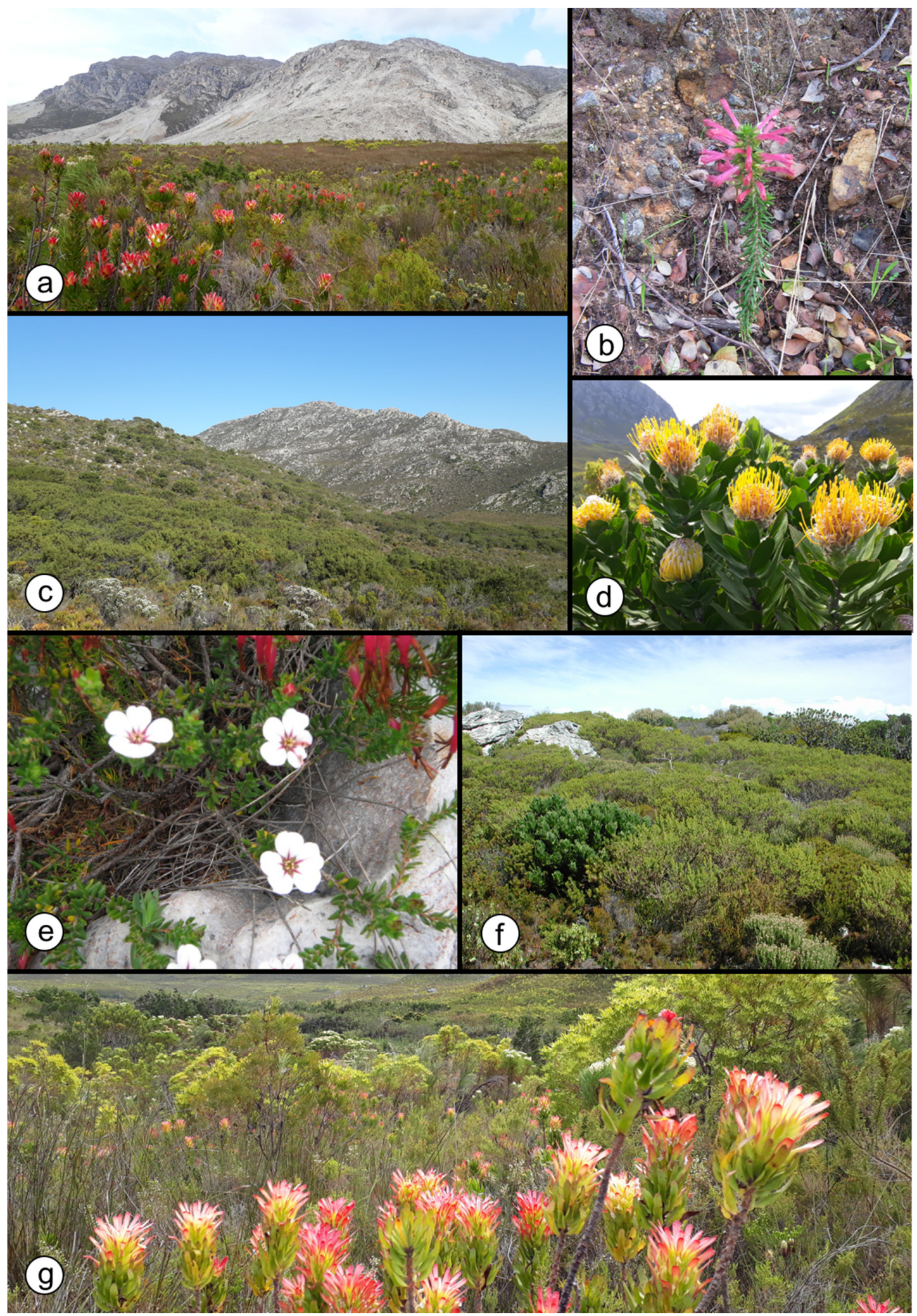

Figure 3. Examples of fynbos plants and vegetation. (a) Kogelberg Sandstone fynbos (photo: T. Conradie). (b) Erica flowers. (photo: K. Jacobs). (c) Elgin Sandstone near Pringle Bay (photo: T. Conradie). (d) Leucospermum (Pincushion) flowers (photo: T. Conradie). (e) Coleonema pulchellum (Confetti bush) flowers (photo: K. Jacobs), (f) Peninsula sandstone fynbos at Cape point (photo: K. Jacobs). (g) Protea flowers in bloom (photo: T. Conradie). 


\section{Microorganisms in Natural Fynbos}

Microbial fynbos communities tend to be transient and the compositions of these communities are strongly affected by abiotic factors, particularly $\mathrm{pH}$, moisture and the availability of nutrients $[11,36,37]$. This was evident from several studies $[10,11,38]$ that showed a clear shift in the bacterial community structure associated with the rhizosphere of native fynbos species between wet and dry seasons, while another study [39] also showed a strong effect of soil $\mathrm{pH}$ on microbial structure. Many microbial species also have the ability to switch between an active and dormant state, making them more resilient and resistant to stress in the environment [37,38], and this is most likely the case with species in the fynbos. However, it is important to note that plant-soil interactions are not simple, and usually involve a consortium of organisms with many complex interactions that influence the outcome [31]. From the limited number of studies looking at the microbial species associated with native fynbos plants, it is evident that there is a large number of novel species in this environment, although the majority of these remain undescribed and their function unknown.

\subsection{Fungi}

Mycorrhizal associations occur in $80 \%$ of land plants [40] and play an important role in the physiology and health of both the host plant and the fungal symbiont. The arbuscular mycorrhizal fungi (AMF) are mostly believed to be the largest group of plant symbionts and around $62 \%$ of fynbos plants are able to form associations with AMF, while $9 \%$ are ericoid mycorrhizal, $2 \%$ have orchid mycorrhizae, mostly associated with Disa spp., and 27\% are non-mycorrhizal [41]. These estimates vary depending on the vegetation type and invasion status. Lower colonisation rates of these mycorrhizal fungi (42\% of plant species) have been reported from some areas $[42,43]$ as a result of disturbances. For example, the colonisation rates of AMF decreased after fire events, but was able to increase again after two growing seasons [43].

AMF have co-evolved with plants throughout evolution [40,44]. Although AMF is known to assist plants in phosphorus and nitrogen acquisition [41,45], they are absent from proteaceous plants in low nutrient soils [41], even though they can form AMF associations with these plants in soils with a higher nutrient content [41]. One study showed that the cost of maintaining mycorrhizal associations increases with plant density in some fynbos plants [46]. The long-term relationship of plants and AMF allowed plants to adapt to a range of environmental changes, albeit slowly [44]. Arbuscular mycorrhizae are formed by relatively few species of fungi, all of which are members of the phylum, Glomeromycota. Although there are a number of studies investigating the presence of AMF in the fynbos, very little is known about their diversity. Known species from the genera Achaeospora and Glomus have been found to be associated with plants from the fynbos [45,47].

Not all root associated fungi belong to the Glomeromycota. The Ericaceae is a large group of flowering plants in the fynbos biome that forms mycorrhizal (ERM) associations with non-vesicular-arbuscular species. The evolution of ERM and the diversification of the fungi involved in mycorrhizal associations were instrumental in the spread of plants into new and different habitats, especially those with nutrient-poor soils $[40,44,48,49]$. Of the approximately 840 known Erica spp., about 680 are found within the fynbos biome, and this profusion of ericaceous host plants, together with the oligotrophic nature of the soil, suggests that ericoid mycorrhizal fungi could be abundant in fynbos soils [50-52]. This intense speciation has led to the suggestion that, if ericoid mycorrhizae are required by ericaceous plants for growth and survival in harsh edaphic conditions, then the fungi forming ericoid mycorrhizae must be abundant in fynbos soils [50]. Although only two surveys of the mycorrhizal status of fynbos plants have been completed, all Erica plants sampled did have ericoid mycorrhizal associations [41,50], showing that these associations, and therefore the fungi forming ericoid mycorrhiza, are common and widespread in the fynbos region. However, neither of these studies identified the endophytes involved in these associations. Robinson was unable to identify his isolates as they remained sterile in culture (although one isolate was tentatively identified as Hypoxylon sp.). Ericoid mycorrhizal fungi from Erica plants growing in the fynbos region were used to 
characterize the dual phosphate uptake system of ericoid mycorrhizal fungi, however, none of the isolates from these studies were identified [41,50,53-56].

Ericoid mycorrhizae are the most common mycorrhizal type formed in the roots of members of the Ericales. These plants have unique root systems lacking root hairs. Instead, they have ephemeral hair roots: fine, reduced root structures that are most active during moist seasons [57,58]. Although their root systems are dominated by ericoid mycorrhizae, dark septate endophytes and other ectomycorrhizae are also found [59]. Yet, to date, little research has been undertaken on the presence of these fungi in the fynbos biome $[41,60,61]$. Ericoid mycorrhizae are distinguished from other mycorrhizal types by the distinct hyphal coils that form in the epidermal cells of colonized hair roots. Although adjacent cells may be colonized, each cell is penetrated separately by hyphae growing alongside the root and no lateral colonization occurs $[57,58]$. Therefore, it is possible for different fungal species to form ericoid mycorrhizal coils in adjacent epidermal cells. Furthermore, no Hartig net or mantle are formed, and arbuscules are not present [62].

In ericoid mycorrhizal associations, the fungal symbiont sequesters nitrogen and phosphate for the host plant and protects the host from high levels of organic acids in the soil in exchange for carbon $[57,58,63]$. This allows ericaceous plants to grow in habitats with acidic and nutrient-poor soils, such as heathlands and sub-alpine forests. It is thought that the ability of ericaceous plants to thrive in these unfavourable soil conditions is the result of their ericoid mycorrhizal (ECM) associations [62]. The diversity of habitats in which ericaceous plants are found suggests that the ericoid mycorrhizal association fulfils a range of functions, depending on the symbiotic partners involved and the environmental conditions in which the association forms [57]. From an unpublished study, the dominant fungal genus isolated from the common Erica mammosa (nine-pin heath), was Oidiodendron, while another two representatives were identified as Cryptosporiopsis ericae and Cryptosporiopsis brunnea. Based on a molecular study of fynbos soils, the common ECM species, Pezizella ericae, Meliniomyces bicolor and Meliniomyces vraolstadiae, have been detected in bulk soil samples from different sites in the fynbos [47] (Figure 4), and most likely form associations with Erica spp. in the fynbos biome.

There are many other fungal species associated with both the above and belowground environment of native fynbos biomes. Over the last six decades, various studies reported unique and diverse fungal species from this environment. Although many of these studies are focused on single or only a few plants or habitats, they have contributed to our knowledge of fungi in this biome. Crous et al. [64] estimated that there could be around 171,500 fungal species associated with plants in the fynbos. This is most likely an underestimate as a 1:7 plant to fungus ratio was used, and this estimate does not include those species isolated from soil or insects. No estimate for bacterial diversity in the fynbos are available to date.

Most fungal studies focused on the above ground parts of fynbos plants [65-73] or with obvious disease symptoms [68,74-80]. It is interesting to note that many species are unique to the fynbos, and appear to be endemic [12-15,81-83]. Roets et al. [84] further showed that many of the above ground plants show seasonal trends in their colonisation pattern, as well as host specificity. This further strengthens the hypothesis that the high diversity in plant species is reflected in the fungal populations.

Species of the genera Penicillium and Talaromyces, are surprisingly well represented in the fynbos [12-15]. These groups have not been well documented $[70,85]$ until recently when a series of studies showed these to be the dominant genera in the fynbos soil biome $[12,13,15,47,86]$ and associated with the above ground structures of various proteaceous plants $[12-15,82,83]$. The number of species from this area is unexpectedly high with more than 80 species recovered of which almost half are novel $[12-15,80,81]$ (Figure 4). Despite this significant addition to the records of fungi from fynbos, very little is known about the role they play. 


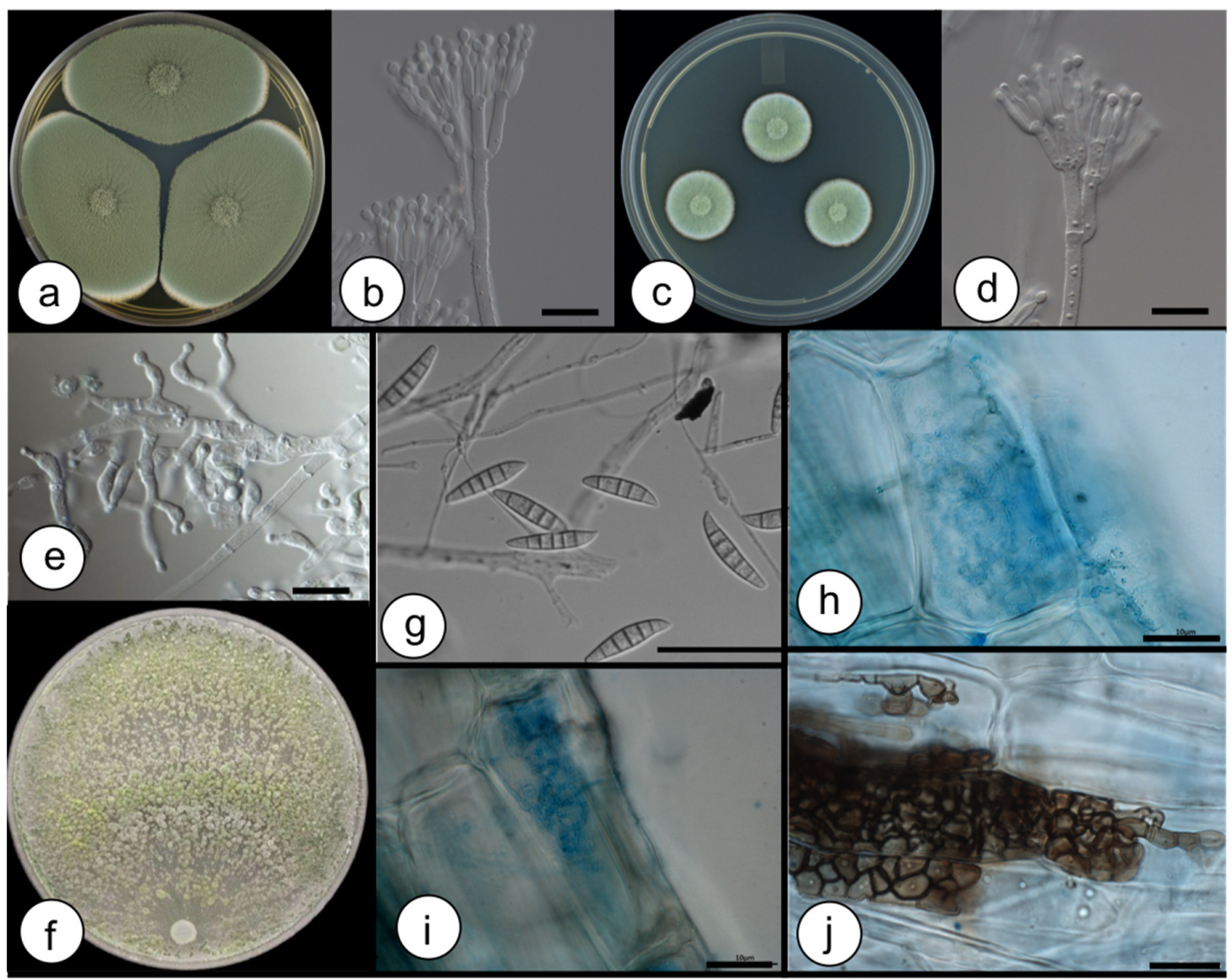

Figure 4. Examples of fungi isolated from fynbos soils and plants. (a,b) Colony morphology and conidiophore morphology of Penicilium crustosum isolated from fynbos soil (photo: CM Visagie). $(\mathbf{c}, \mathbf{d})$ Colony morphology and conidiophore morphology of Penicilium pumilaemali isolated from fynbos soil (photo: CM Visagie). (e,f) Conidiophore morphology and colony morphology of Trichoderma saturnispora isolated from fynbos soil (photo: IH du Plessis). (g) Conidia of an undescribed Fusarium sp. isolated from Table Mountain (photo: V Bushula). (h,i) Mycorrhizal structures observed in Erica mammosa hair roots (photo: K Wirth). j. Dark septate endophytes observed in Erica mammosa hair roots. (photo: K Wirth). (All scale bars $=10 \mu \mathrm{m}$ ).

Very little is also known about the presence of yeasts in the fynbos biome. A basidiomycetous yeast, Cryptococcus laurentii, was isolated from the rhizosphere of the indigenous, medicinal plant Agathosma betulina (buchu) [87]. This species was able to colonize the root surface and influence the growth of the plant. Another study [88] showed that the yeast populations of fynbos are mostly influenced by moisture. In Mediterranean systems in other parts of the world, it was shown that the length of a dry summer can have an effect on the structure and function of the microbial communities [89]. This is important as the fynbos region experience very dry summers, frequent fires and occasional droughts, which would have a major impact on the microbial community structure and function.

\subsection{Bacteria}

Bacteria in the fynbos biome have not been intensively studied, and the focus has mostly been on characterising bacterial communities and the effect of disturbance on these communities $[10,11,19,38]$. Most studies found that the overall bacterial diversity associated with fynbos plants was high, and that these communities appear to be selected by the plant species, possibly through several different mechanisms. The commercialisation of native plant species does not appear to have a major effect on the overall community composition, although closer investigation of these communities reveals an impact on selected groups. However, these communities are heavily influenced by seasonal changes, 
with a shift in moisture and temperature. This should raise some questions to the effect of climate change in these areas which are expected to become dryer and warmer in the next few decades [90].

It has been suggested that bacterial groups evolved in this biome to be hyper-diverse and in many cases some species are only found in this part of the world as was the case with Burkholderia [91,92] and Paraburkholderia [93]. This group of bacteria functions as symbionts of plants to acquire nitrogen through fixation [94]. Although the strains isolated from fynbos plants do not show distinct biogeographic distribution patterns, and were not host-specific, Burkholderia spp. appears to have nodulation genes that are closely related and only form nodules in the presences of fynbos papilionoid legumes [95]. Numerous studies isolated and characterised species from this bacterial group, including some novel strains $[91,93,96]$. Most of the strains isolated from fynbos plants are shown to be highly adapted to low $\mathrm{pH}$ environments, consistent with the fynbos soils [97].

Actinomycetes are commonly known as soil bacteria, and can be readily detected from fynbos soils [88]. This bacterial group was recently found to also inhabit the infructescences of Protea flowers, and appear to be closely associated with the ophiostomatoid fungi that are regularly associated with the mites inhabiting these habitats [98]. These bacteria are assumed to play an important role in the structuring of the microbial communities in the above ground infructescence as they produce an arsenal of anti-bacterial and anti-fungal compounds and would, therefore be able to select for certain species of fungi and bacteria. As fire is a common occurrence in the fynbos biome, unrestricted fires may have a severe impact on the distribution patterns of these species [98].

One bacterial phylum of interest within the fynbos biome is the Acidobacteria. This bacterial group is commonly found in most soil environments and can represent up to $50 \%$ of the $16 \mathrm{~S}$ rRNA gene sequences $[99,100]$ in molecular studies. Acidobacteria prefer oligotrophic soil environments with a low $\mathrm{pH}[101,102]$ and should, therefore be ideally suited to the fynbos environment. In the fynbos biome the Acidobacteria has a relative abundance between 4-26\% [10,11,16,38,103,104], with a higher relative abundance estimated in the sand fynbos [104]. The Acidobacteria is divided into 15 subdivisions (formerly 26) [105]. In the fynbos biome, subdivisions 1 (Acidobacteriales), 2 and 3 (Solibacterales) are most commonly found $[10,16,38,106]$. Although the Acidobacteria is one of the most dominant phyla within the fynbos biome, more than $40 \%$ of the acidobacterial affiliated sequences generated with $16 \mathrm{~S}$ amplicon sequencing are unclassified or unknown. This raises more questions than answers when trying to understand why they are so prominent and what their functions are. Recent advances in metagenomic and proteomic research have started to fill this gap. A study on Mediterranean grassland soil, which is similar to fynbos soil, revealed acidobacterial genomes that encode for large enzyme complements for the degradation of complex carbohydrates (CAZy), making them suitable in an environment where nutrient cycles are microbial driven [107]. Subdivisions 1, 2 and 3 had the highest diversity of CAZy enzymes. They also found that at least one member of the Acidobacteria phylum contained $73 \%$ of CAZy classes, which include carbohydrate esterase, glycosyl hydrolase, auxiliary activity, and polysaccharide lyase [107]. Many genomes also possess gene that encode for the capacity to use organic and inorganic nitrogen sources, and the ability to scavenge for atmospheric hydrogen (specifically in subdivisions 1 and 3) [102,107-109]. These traits, together with the ability to use diverse carbohydrates, are advantageous in soil environments where nutrient availability is low and fluctuates between seasons.

\subsection{Viruses}

Very little is known about the virome of the fynbos biome. In a limited study [110], it was found that soils from this area have a diverse representation of viral genomes, while the majority of the gene fragments detected belong to the order Caudovirales, and the majority of the sequences represented bacteriophages. This should not be surprising considering the rich bacterial communities in this domain $[10,11,17,93]$. The role of these phages in nature is generally considered to be maintaining diversity in populations [111], as well as playing an important part in nutrient cycling [112]. 


\section{Alien Plant Invasion in the Fynbos Biome}

Alien plant invasion poses a major threat to fynbos vegetation. In 1995, the Working for Water (WfW) program introduced the combined application of mechanical removal and chemical control to remove the invasive species and promote the recovery of fynbos vegetation [8,113-115] (Figure 5). The National Environmental Management: Biodiversity Act (Act 10 of 2004) promulgated actions to control alien plant invasion in fynbos to reduce the area of ecosystems under threat, and prevent the extinction of indigenous species. Actions are also designed to prevent the loss and degradation of soil structure, the function of threatened ecosystems as well as to protect regions of high conservation importance. Over ZAR 15 billion ( $\$ 9$ billion) has been spent to control various invasive species [115]. Nationally, as well as locally in the CFR, mechanical removal and subsequent chemical control are widely used to reduce alien plant invasion.

Several Acacia spp., Eucalyptus spp., and to a lesser extent species of Pinus are major threats to the fynbos vegetation, many of which are considered transformer species, i.e., invasive species that alter the character and nature of recipient ecosystems [116]. Invasive species in both the genera Acacia and Eucalyptus have specific adaptations that allow them to outcompete native species [117-119], which may lead to a significant decline in native species richness [120]. Acacia spp. are more widely distributed in fynbos compared to Eucalyptus spp. [121], and their litter production is greater [122,123]. Invasive alien plant species from areas with similar climates have stronger impacts in invaded environments [120], which means that invasive alien plants from other Mediterranean ecosystems have a much larger impact on the native fynbos biome. In general, invasion by particularly Acacia, has significant impacts, which increase with time, including altered soil properties, change in light regime, production of allelopathic compounds and many more. In addition, Acacia spp. generate massive seed banks which can take considerable effort and time to manage [124]. In other Mediterranean ecosystems, invasion by Acacia dealbata was shown to have significant effects on the soil chemistry as well as the structuring of microbial communities [125].

Both Acacia and Eucalyptus spp. produce litter that influence soil and biogeochemical processes, which ultimately alters the ecosystem functioning $[47,117,126]$. The phosphorus concentration in the leaves and litter of Acacia and Eucalyptus spp. are similar [122], however, the nitrogen concentration of Acacia spp. litter is relatively higher due to the plants' ability to fix atmospheric nitrogen through nodulating bacteria [122]. In riparian zones, Acacia litter was enriched in nitrogen, and A. mearnsii resorbed phosphorus rather than nitrogen from senescent leaves, mainly due to the abundance of nitrogen rather than phosphorus in foliage of the nitrogen-fixer $[127,128]$. Litter rich in nitrogen compared to carbon increases the availability of nitrogen in soil through accelerated decomposition and mineralization [128], which increases the abundance and growth rate of Acacia spp. [129,130]. 


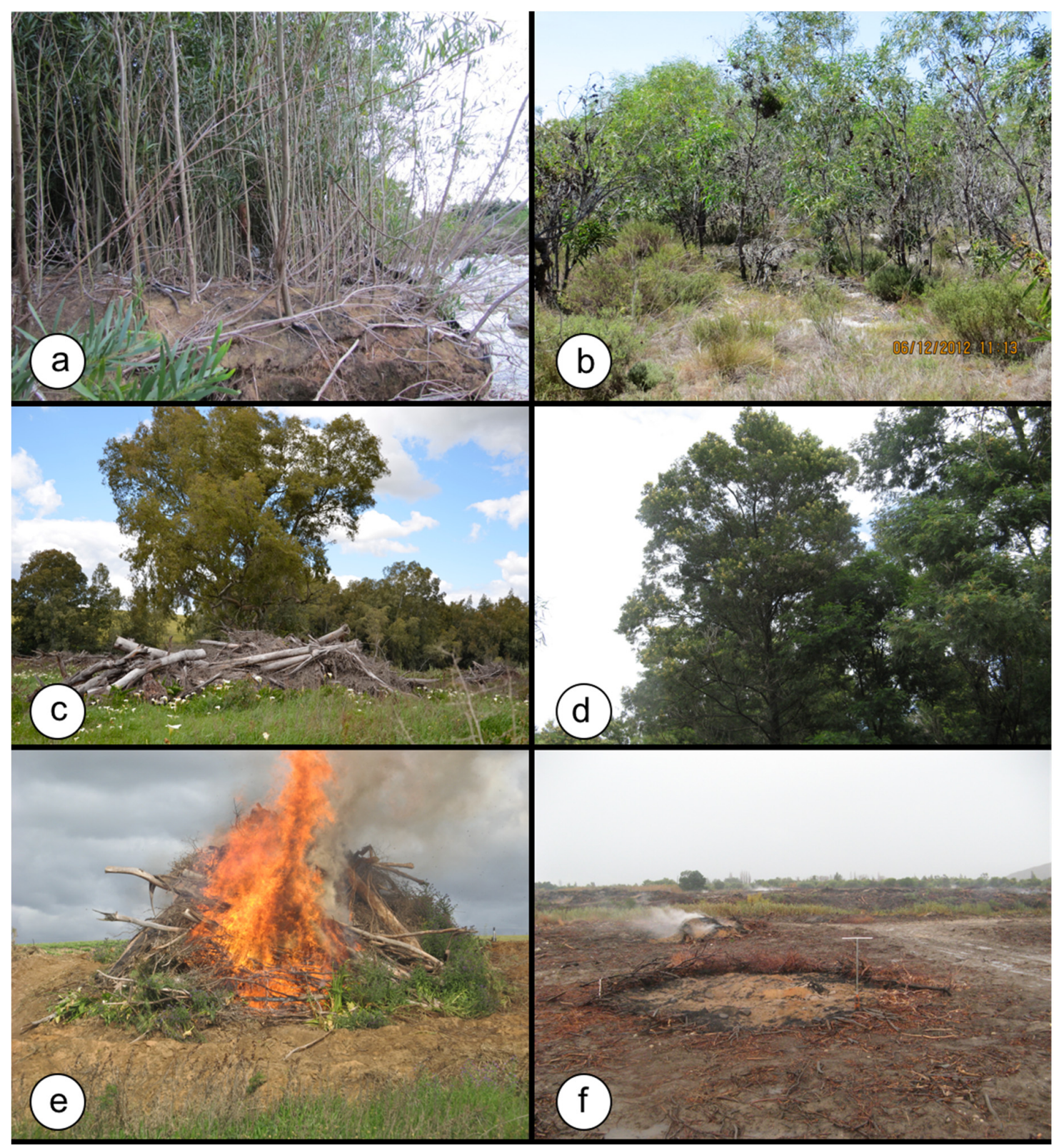

Figure 5. Examples of invasive alien plants in the fynbos biome. (a) Extensive invasion of riparian zones by Acacia saligna (photo: E. Slabbert). (b) A. saligna growth in the Blaauwberg Nature Reserve park (photo: E. Slabbert). (c) Mature Eucalyptus camaldulensis growing in a riparian zone along the Berg River at Hermon, with a large pile of alien invasive biomass in the foreground (photo: T. Maubane). (d) A large Acacia mearnsii tree along the Breede River at Rawsonville (photo: T. Maubane). (e) Burning piles of invasive alien plants during slash and burn removal (photo: S. Jacobs). (f) The aftermath of burned slash piles, which in some cases may result in permanent burn scars (photo: T. Maubane).

\section{Changes in Soil Properties}

The effect of invasive alien plants on the soil chemistry of fynbos soils can be profound, and by extension should have an influence on the native soil microbial communities. Studies from other Mediterranean ecosystems show that invasive plants significantly change the soil chemistry which leads to an altered microbial community [131]. A. mearnsii invasion in the fynbos region drastically alter the soil chemistry with a pronounced effect on the soil microbial communities [11]. Similarly, Yelenik et al. [130] found more than a two-fold increase in soil total available carbon and total nitrogen under $A$. saligna compared to nearby fynbos sites. In riparian environments, a significant 
increase in total nitrogen was observed [39], although lower in magnitude compared to the terrestrial sites [130]. This is likely due to loss of soil nitrogen through various hydrological pathways in riverine environments. Available nitrogen also rose significantly in riparian soils, showing the ability of invasive Acacia spp. to alter soils and transform ecosystems. In contrast, riparian soils receiving Eucalyptus litter were not enriched in total nitrogen [132], similar to the lack of a change in soil $\mathrm{N}$ with invasion of Eucalyptus spp. in terrestrial soils in a grassy fynbos ecosystem [133]. The alterations in soil nitrogen is thought to be reversible after removal of the nitrogen fixing invasive species, however, several studies showed legacies exist in the form of high levels of available nitrogen well after removal of the invaders [39,130,134]. This may have significant consequences for soil ecology [134], including altering the trajectory of restoration.

The effect of Acacia invasion on soil phosphorus is more complex, with no differences in available phosphorus between invaded and natural riparian soils [39]. However, terrestrial soils under Acacia cyclops and $A$. saligna stands accumulated higher available phosphorus compared to native fynbos stands $[135,136]$. For Eucalyptus invasion, available phosphorus in terrestrial Eucalyptus stands was elevated, which declined upon removal of the invasive trees [133]. Invasive Acacia, however, increased acid phosphatase enzyme activity in soils, suggesting that more phosphorus might be available in soils of such invasive stands, though it may be taken up rapidly by the invasive acacias, hence an increase in available phosphorus is not reflected in bulk soil. There is some evidence that showed that soil phosphorus in fynbos riparian soils is linked to bacterial community structure; thus invasion and subsequent changes to soil phosphorus can have significant consequences for soil ecology [11].

Invasion by Acacia and Eucalyptus spp. into fynbos can also alter soil pH. Invasion of Eucalyptus increased soil $\mathrm{pH}$ in grassy fynbos [133], while invasion by Eucalyptus camaldulensis in riparian zones depressed soil $\mathrm{pH}$ by up to 0.3 units [118]. Given that soil $\mathrm{pH}$ is strongly linked to soil bacterial community structure, any alteration to soil $\mathrm{pH}$ can have major consequences for soil ecology. There are also other impacts, such as an increase in soil hydrophobicity with Eucalyptus invasion [137], and an interaction between invasion and fire can alter hydrophobicity in areas where Acacia biomass have been stacked and burned [138]. Eucalyptus litter also produces allelochemical compounds, which are elevated in soils underneath Eucalyptus stands in riparian environments [137]. This advantage that Eucalyptus spp. has in its invaded range is suggestive of the novel weapons hypothesis (Table 1).

\section{The Role of Microorganisms in Invasion}

Soil microbial communities can influence invasion, both positively and negatively. It can do so through enhancing or suppressing germination, have positive or negative feedback systems, engage in symbiotic interactions or alternatively influence soil nutrient cycles and soil enzyme concentrations [139-141]. Numerous hypotheses have been put forward to explain or understand the role of microorganisms in the success of invasive plant species [141,142] (Table 1). However, very little research has been undertaken on the role of microorganisms on the success of invasive plants into the fynbos biome.

Introduction of microorganisms into the fynbos biome is not unprecedented. Introducing novel alien pathogens into the fynbos biome has been shown to place plants in this biome under even more pressure and may lead to extensive mortality of indigenous plants [143]. The nodulating bacteria found in fynbos soils and associated with native plants have been studied in some depth. Based on phylogenetic studies, it was shown that the Bradyrhizobium spp. in South African fynbos has the same origin as European species [144], although most of the Bradyrhizobium species associated with Acacia have most likely been co-introduced [145]. Acacia spp. also appears to have both introduced some novel rhizobial species into fynbos areas, but also exploited their symbiotic promiscuous association with local rhizobial species. As nodulating bacteria in general are not considered to be good invaders, Rodríguez-Echeverría et al. [146], suggest that broad symbiotic promiscuity and the ability to nodulate at low rhizobial abundance would be beneficial for Acacia spp. to invade [146]. Evidence of this can be seen in a number of woody legumes that are effective invaders, [143], and it may well be true for alien 
invasive species in the fynbos biome. Distinct bacterial markers are associated with invasion with the numbers of Bradyrhizobium showing a rapid increase in invaded areas, alongside a marked decline in other bacterial groups [11].

In the case of non-nodulating species, such as the invasive Pinus and Eucalyptus, the successful establishment of the tree species relies on its ability to form associations with mycorrhizal symbionts [147]. In the case of Pinus, this is a specific interaction, and the ECM is usually co-introduced with the tree. A lack of ECM may in fact be limiting success of Pinus spp. in some Mediterranean regions. In the case of the genus Eucalyptus, the symbiosis is less specific and Eucalyptus spp. can associate with native ECM [140]. In other parts of Africa, non-native ECM fungi were able to become naturalized, and Eucalyptus spp. were able to form associations with native ECM fungi [147]. This may be true for Eucalyptus and Pinus species in the fynbos, but the evidence is still anecdotal.

Table 1. Different hypotheses that relate to the contribution of invasion success of non-native plants, by microbial interactions with examples from the fynbos biome (Adapted from [141,142]).

\begin{tabular}{|c|c|c|c|}
\hline Hypothesis & Definition & Example & Reference \\
\hline \multirow[t]{2}{*}{$\begin{array}{l}\text { Enemy release } \\
\text { hypothesis }\end{array}$} & \multirow{2}{*}{$\begin{array}{l}\text { Absence of an antagonist } \\
\text { during colonization } \\
\text { results in the successful } \\
\text { establishment of invaded } \\
\text { plant species. }\end{array}$} & $\begin{array}{l}\text { Sirex noctilio(woodwasp), } \\
\text { together with its symbiotic } \\
\text { fungus, Amylostereum } \\
\text { areolatum infested pine trees in } \\
\text { the fynbos region, South Africa } \\
\text { decades after establishment of } \\
\text { invasive pine as plantations. }\end{array}$ & [148] \\
\hline & & $\begin{array}{l}\text { The rust fungus Uromycladium } \\
\text { tepperianum was only } \\
\text { introduced in } 1987 \text { into South } \\
\text { Africa as a biocontrol measure } \\
\text { on Acacia. }\end{array}$ & [149] \\
\hline \multirow{2}{*}{$\begin{array}{l}\text { Enhanced mutualism } \\
\text { hypothesis (novel } \\
\text { mutualism) }\end{array}$} & \multirow{2}{*}{$\begin{array}{l}\text { Invasive plant species } \\
\text { associate with native soil } \\
\text { mutualists in its } \\
\text { introduced ranges which } \\
\text { leads to } \\
\text { successful invasion. }\end{array}$} & $\begin{array}{l}\text { Acacia has been shown to } \\
\text { recruit non-specific rhizobia } \\
\text { that are native to the fynbos } \\
\text { for nodule forming. }\end{array}$ & [146] \\
\hline & & $\begin{array}{l}\text { Eucalyptus has been shown to } \\
\text { recruit native ectomycorrhizae } \\
\text { in other areas of Africa. This } \\
\text { has, however, not been shown } \\
\text { for species invasive in fynbos, } \\
\text { but are likely to occur. }\end{array}$ & [147] \\
\hline $\begin{array}{l}\text { Degraded mutualism } \\
\text { hypothesis }\end{array}$ & $\begin{array}{l}\text { The invasion of an area } \\
\text { by non-mycorrhizal } \\
\text { plants reduces the } \\
\text { abundance of arbuscular } \\
\text { mycorrhizal (AM) fungi. }\end{array}$ & $\begin{array}{l}\text { The invasion of an area by } \\
\text { nonmycorrhizal plants } \\
\text { reduces the abundance of } \\
\text { arbuscular mycorrhizal fungi } \\
\text { (AMF). However, a change in } \\
\text { the nutritional status or the } \\
\text { absence of important fynbos } \\
\text { species such as the Proteaceae } \\
\text { may disproportionately select } \\
\text { for the re-establishment of } \\
\text { AMF-plants, to the detriment } \\
\text { of the ECM } \\
\text { (Ectomycorrhizal)-plants. }\end{array}$ & \\
\hline
\end{tabular}


Table 1. Cont.

\begin{tabular}{|c|c|c|c|}
\hline Hypothesis & Definition & Example & Reference \\
\hline $\begin{array}{l}\text { Accumulation of local } \\
\text { pathogen hypothesis }\end{array}$ & $\begin{array}{l}\text { This suggests that } \\
\text { invasive alien plant } \\
\text { species gather native soil } \\
\text { pathogens that restrict } \\
\text { native plant spread } \\
\text { and growth. }\end{array}$ & No evidence. & \\
\hline $\begin{array}{l}\text { Novel weapon } \\
\text { hypothesis }\end{array}$ & $\begin{array}{l}\text { This postulates that } \\
\text { invasive plants possess } \\
\text { new biochemical } \\
\text { weapons that function as } \\
\text { strong allelopathic } \\
\text { agents for new } \\
\text { plant-soil-microbe } \\
\text { interactions. }\end{array}$ & $\begin{array}{l}\text { Slash and burn of Eucalypt } \\
\text { during removal of invasive } \\
\text { alien plants had a lasting } \\
\text { legacy effect on the recovery of } \\
\text { native fynbos and changed the } \\
\text { soil bacterial communities } \\
\text { over an extended time period, } \\
\text { most likely as a result of } \\
\text { allelochemicals released } \\
\text { during decomposition, } \\
\text { exacerbated by fire. }\end{array}$ & {$[139,150]$} \\
\hline
\end{tabular}

\section{Effect of Restoration on Microbial Communities}

There are many efforts and programmes focused on the restoration of invaded fynbos sites, with various levels of success. These include clearance and removal of the biomass, through various means. In some cases, this is effective, but in most instances, a complex set of interactions are required, such as the re-adjustment of the soil chemistry, reintroduction of native plants and intensive management [116]. It has been suggested that the re-establishment of Protea spp., are not influenced as much by the altered soil chemistry as a result of the presence of non-native grass species, but as a result of the presence of beneficial microorganisms in soil [151]. An altered soil microbial community as a result of altered soil chemistry, may, therefore, have a profound effect on the re-establishment of fynbos species in cleared sites, altering the trajectory of recovery, or allowing secondary invasions to take place [152].

The removal of Acacia from riparian zones allowed the bacterial communities to recover to one almost resembling the original, over time, with a recovery of native fynbos [11]. One of the most effective ways to remove invasive alien plants is through a slash and burn protocol. This method entails the manual removal of invasive alien plants and stacking the biomass in piles which is then burned (Figure 5). In some cases, the burn will leave a permanent burn scar with little or no recovery of the native fynbos. Burning of Acacia and Eucalyptus biomass has very different outcomes [150]. In the case of the Acacia, the soil bacterial populations will show a shift over the immediate to short term period, while a return to an almost natural fynbos microbial composition is seen over a period of 12 months. However, in the case of Eucalyptus, this shift in microbial composition remains after 12 months, with little recovery of the natural vegetation. One of the reasons for this could potentially be the release of toxins and chemicals from Eucalyptus into the soil during decomposition [139], exacerbated by burning. Another factor that could alter the trajectory of restoration following clearing is that soil $\mathrm{pH}$ can increase by up to two units following burning of biomass piles, possibly due to the release of cations during burning [138]. Differences in soil $\mathrm{pH}$ become less pronounced by the end of the first year, which parallels the recovery in soil microbial population structure. Further, following removal of alien invasive trees, herbicides are applied to suppress regrowth. However, the application of herbicide, should it reach soils, could reduce soil $\mathrm{pH}$, showing that soil $\mathrm{pH}$, a major driver of soil microbial diversity, is an important variable that is affected by restoration interventions following clearing and alien species management in riparian and terrestrial areas [138]. This highlights the necessity for a tailored approach to rehabilitation. 


\section{Looking Forward}

Given the dearth of information on the diversity of microbial taxa in the CFR, and the threats on plant biodiversity experienced in this globally recognized hotspot, more focused attention is needed on understanding bacterial, fungal and viral biodiversity. This is especially pertinent given the mutualistic relationships between plants and fungi, and the general reliance of endemic fynbos species on particularly fungi and bacteria for survival in this nutrient-poor environment. Although there has been some progress into disentangling the role of microbial communities in the fynbos, there is still much to be done. Research efforts should focus on documenting and characterizing fungal and bacterial species associated with fynbos plants, and not only focus on those causing disease. In addition, high-throughput isolation and molecular methods should be employed to understand the dynamics and function of these communities. Research should focus on restoration practices that will restore and encourage growth of native microbial species, which in turn will enhance the growth of plants in these areas. The identification of keystone microbial species can allow for prioritising restoration projects for greater success, by identifying areas with microbial communities that will enable restoration. However, this will only be possible if efforts to characterise the microbial communities form part of larger conservation efforts and programmes.

\section{Conclusions}

Fynbos plants co-evolved with microbial communities and have adapted to much of the limitations on plant growth by engaging in mutualistic relationships with, e.g., fungi to form ericoid mycorrhiza, and with Burkholderia for enhancing nitrogen availability. The existence of other relationships that support the remarkable plant diversity remains unknown, as well as whether this plant diversity is also reflected in a high microbial diversity. The few studies available suggest that this might be the case. Invasion by woody invasive alien plants leads to a major shift in the soil microbial community, which is partially restored when the woody invasive alien plants are removed. A clearer understanding of barriers to restoration of native fynbos plants may be gained through more focused and systematic studies on what happens to soil microbial communities during invasion and after the clearing of invasive alien plants, although the management approach and practices associated with clearing, e.g., use of fire to get rid of biomass, have their own implications for microbial communities. With the double threat of global warming and a growing population, the fynbos biome, like many other ecosystems, is under severe stress. Our ability to respond to these multiple anthropogenic stressors will be severely lacking without a more complete understanding of the microbial communities of the fynbos biome.

Author Contributions: Conceptualization, K.J. and S.J.; Writing-Original Draft Preparation, K.J., S.J. and T.C.; Writing-Review and Editing, K.J., S.J. and T.C.; Funding Acquisition, K.J. and S.J. All authors have read and agreed to the published version of the manuscript.

Funding: The paper is based on a number of projects funded by the National Research Foundation of South Africa and the Water Research Commission, South Africa.

Acknowledgments: The authors of this article would like to thank Charmaine Oxtoby from the City of Cape Town Biodiversity Management Branch, for permission to use Figures 1 and 2, from their report. We also like to acknowledge and thank the reviewers for their valuable comments and suggestions to improve this paper.

Conflicts of Interest: The authors declare no conflict of interest.

\section{References}

1. Myers, N. Biodiversity hotspots revisited. Bioscience 2003, 53, 916-917.

2. Goldblatt, P.; Manning, J. Plant Diversity of the Cape Region of Southern Africa. Ann. Missouri Bot. Gard. 2002, 89, 281-302. [CrossRef]

3. Manning, J.; Goldblatt, P. Plants of the Greater Cape Floristic Region. 1: The Core Cape flora; Strelitzia 29: South African National Biodiversity Institute: Pretoria, South Africa, 2012; ISBN 978-1-919976-74-7.

4. Goldblatt, P. Floristic diversity in the Cape Flora of South Africa. Biodivers. Conserv. 1997, 6, 359-377. [CrossRef] 
5. Myers, N.; Mittermeler, R.A.; Mittermeler, C.G.; Da Fonseca, G.A.B.; Kent, J. Biodiversity hotspots for conservation priorities. Nature 2000, 403, 853-858. [CrossRef]

6. Rebelo, A.G.; Boucher, C.; Helme, N.; Mucina, L.; Rutherford, M.C. Fynbos Biome. In The vegetation of South Africa, Lesotho and Swaziland; Mucina, L., Rutherford, M.C., Eds.; Strelitzia 19: South African National Biodiversity Institute: Pretoria, South Africa, 2006; pp. 52-219, ISBN 1978-1-919976-21-1.

7. Van Wilgen, B.W. The evolution of fire management practices in savanna protected areas in South Africa. S. Afr. J. Sci. 2009, 105, 343-349. [CrossRef]

8. Moran, V.C.; Hoffmann, J.H. Conservation of the fynbos biome in the Cape Floral Region: The role of biological control in the management of invasive alien trees. BioControl 2012, 57, 139-149. [CrossRef]

9. City of Cape Town. City of Cape Town Biodiversity Report 2018; City of Cape Town: Cape Town, South Africa, 2018.

10. Postma, A.; Slabbert, E.; Postma, F.; Jacobs, K. Soil bacterial communities associated with natural and commercial Cyclopia spp. FEMS Microbiol. Ecol. 2016, 92, 1-10. [CrossRef]

11. Slabbert, E.; Jacobs, S.M.; Jacobs, K. The soil bacterial communities of South African fynbos riparian ecosystems invaded by Australian Acacia species. PLoS ONE 2014, 9, e86560. [CrossRef]

12. Visagie, C.M.; Roets, F.; Jacobs, K. A new species of Penicillium, P. ramulosum sp. nov., from the natural environment. Mycologia 2009, 101, 888-895. [CrossRef]

13. Visagie, C.M.; Seifert, K.A.; Houbraken, J.; Samson, R.A.; Jacobs, K. Diversity of Penicillium section Citrina within the fynbos biome of South Africa, including a new species from a Protea repens infructescence. Mycologia 2014, 106, 537-552. [CrossRef]

14. Visagie, C.M.; Houbraken, J.; Seifert, K.A.; Samson, R.A.; Jacobs, K. Four new Penicillium species isolated from the fynbos biome in South Africa, including a multigene phylogeny of section Lanata-Divaricata. Mycol. Prog. 2015, 14, 1-23. [CrossRef]

15. Visagie, C.M.; Seifert, K.A.; Houbraken, J.; Samson, R.A.; Jacobs, K. A phylogenetic revision of Penicillium sect. Exilicaulis, including nine new species from fynbos in South Africa. IMA Fungus 2016, 7, 75-117. [CrossRef] [PubMed]

16. Keet, J.H.; Ellis, A.G.; Hui, C.; Le Roux, J.J. Strong spatial and temporal turnover of soil bacterial communities in South Africa's hyperdiverse fynbos biome. Soil Biol. Biochem. 2019, 136, 107541. [CrossRef]

17. South African National Biodiversity Institute (SANBI). Biodiversity GIS Spatial Dataset. Available online: http://bgis.sanbi.org/SpatialDataset (accessed on 4 May 2020).

18. Slabbert, E.; Kongor, R.Y.; Esler, K.J.; Jacobs, K. Microbial diversity and community structure in Fynbos soil. Mol. Ecol. 2010, 19, 1031-1041. [CrossRef]

19. City of Cape Town Open Data portal. Available online: https://web1.capetown.gov.za/web1/OpenDataPortal/ AllDatasets (accessed on 4 May 2020).

20. Cowling, R.M.; Procheş, S..; Partridge, T.C. Explaining the uniqueness of the Cape flora: Incorporating geomorphic evolution as a factor for explaining its diversification. Mol. Phylogenet. Evol. 2009, 51, 64-74. [CrossRef]

21. Cowling, R.M.; Potts, A.J.; Bradshaw, P.L.; Colville, J.; Arianoutsou, M.; Ferrier, S.; Forest, F.; Fyllas, N.M.; Hopper, S.D.; Ojeda, F.; et al. Variation in plant diversity in mediterranean-climate ecosystems: The role of climatic and topographical stability. J. Biogeogr. 2015, 42, 552-564. [CrossRef]

22. Pirie, M.D.; Oliver, E.G.H.; Gehrke, B.; Heringer, L.; De Kuppler, A.M.; Le Maitre, N.C.; Bellstedt, D.U. Underestimated regional species diversity in the Cape Floristic Region revealed by phylogenetic analysis of the Erica abietina/E. viscaria clade (Ericaceae). Bot. J. Linn. Soc. 2017, 184, 185-203. [CrossRef]

23. Allsopp, N.; Colville, J.F.; Verboom, G.A. Fynbos: Ecology, Evolution and Conservation of a Megadiverse Region; Allsopp, N., Colville, J.F., Verboom, G.A., Cowling, R.M., Eds.; Oxford University Press: London, UK, 2014; ISBN 978-0-199679-58-4.

24. Maistry, P.M.; Muasya, A.M.; Valentine, A.J.; Chimphango, S.B.M. Increasing nitrogen supply stimulates phosphorus acquisition mechanisms in the fynbos species Aspalathus linearis. Funct. Plant Biol. 2015, 42, 52-62. [CrossRef] [PubMed]

25. Mariotte, P.; Mehrabi, Z.; Bezemer, T.M.; De Deyn, G.B.; Kulmatiski, A.; Drigo, B.; Veen, G.F.; van der Heijden, M.G.A.; Kardol, P. Plant-Soil Feedback: Bridging Natural and Agricultural Sciences. Trends Ecol. Evol. 2018, 33, 129-142. [CrossRef] [PubMed] 
26. Curiel Yuste, J.; Fernandez-Gonzalez, A.J.; Fernandez-Lopez, M.; Ogaya, R.; Penuelas, J.; Sardans, J.; Lloret, F. Strong functional stability of soil microbial communities under semiarid Mediterranean conditions and subjected to long-term shifts in baseline precipitation. Soil Biol. Biochem. 2014, 69, 223-233. [CrossRef]

27. Bonkowski, M.; Villenave, C.; Griffiths, B. Rhizosphere fauna: The functional and structural diversity of intimate interactions of soil fauna with plant roots. Plant Soil 2009, 321, 213-233. [CrossRef]

28. Maseko, S.T.; Dakora, F.D. Plant Enzymes, Root Exudates, Cluster Roots and Mycorrhizal Symbiosis are the Drivers of P Nutrition in Native Legumes Growing in P Deficient Soil of the Cape Fynbos in South Africa. J. Agric. Sci. Technol. 2013, 3, 331-340.

29. Maseko, S.T.; Dakora, F.D. Rhizosphere acid and alkaline phosphatase activity as a marker of P nutrition in nodulated Cyclopia and Aspalathus species in the Cape fynbos of South Africa. S. Afr. J. Bot. 2013, 89, 289-295. [CrossRef]

30. Brink, C.; Postma, A.; Jacobs, K. Rhizobial diversity and function in rooibos (Aspalathus linearis) and honeybush (Cyclopia spp.) plants: A review. S. Afr. J. Bot. 2017, 110, 80-86. [CrossRef]

31. Chaparro, J.M.; Sheflin, A.M.; Manter, D.K.; Vivanco, J.M. Manipulating the soil microbiome to increase soil health and plant fertility. Biol. Fertil. Soils 2012, 48, 489-499. [CrossRef]

32. Morgan, J.A.W.; Bending, G.D.; White, P.J. Biological costs and benefits to plant-microbe interactions in the rhizosphere. J. Exp. Bot. 2005, 56, 1729-1739. [CrossRef]

33. Badri, D.V.; Vivanco, J.M. Regulation and function of root exudates. Plant Cell Environ. 2009, 32, 666-681. [CrossRef]

34. Tkacz, A.; Cheema, J.; Chandra, G.; Grant, A.; Poole, P.S. Stability and succession of the rhizosphere microbiota depends upon plant type and soil composition. ISME J. 2015, 9, 2349-2359. [CrossRef]

35. Richards, M.B.; Stock, W.D.; Cowling, R.M. Soil nutrient dynamics and community boundaries in the Fynbos vegetation of South Africa. Plant Ecol. 1997, 130, 143-153. [CrossRef]

36. Lauber, C.L.; Hamady, M.; Knight, R.; Fierer, N. Pyrosequencing-based assessment of soil pH as a predictor of soil bacterial community structure at the continental scale. Appl. Environ. Microbiol. 2009, 75, 5111-5120. [CrossRef]

37. Rousk, J.; Bååth, E.; Brookes, P.C.; Lauber, C.L.; Lozupone, C.; Caporaso, J.G.; Knight, R.; Fierer, N. Soil bacterial and fungal communities across a $\mathrm{pH}$ gradient in an arable soil. ISME J. 2010, 4, 1340-1351. [CrossRef] [PubMed]

38. Brink, C.; Postma, A.; Slabbert, E.; Postma, F.; Muasya, A.; Jacobs, K. Bacterial communities associated with natural and commercially grown rooibos (Aspalathus linearis). Pedosphere, in press.

39. Jacobs, S.; Naude, M.; Slabbert, E.; Kambaj, O.; Fourie, M.; Esler, K.; Jacobs, K.; Mantlana, B.; Rozanov, A.; Cowan, D. Identifying Relationships Between Soil Processes and Biodiversity to Improve Restoration of Riparian Ecotones Invaded by Invasive Acacias; WRC Report, No. 1927/1/131; Water Research Commission: Pretoria, South Africa, 2013; p. 151, ISBN 978-1-4312-0445-7.

40. Wang, B.; Qiu, Y.L. Phylogenetic distribution and evolution of mycorrhizas in land plants. Mycorrhiza 2006, 16, 299-363. [CrossRef] [PubMed]

41. Allsopp, N.; Stock, W.D. Mycorrhizal status of plants growing in the Cape Floristic Region, South Africa. Bothalia 1993, 23, 91-104. [CrossRef]

42. Berliner, R.; Mitchell, D.T.; Allsopp, N. The vesicular-arbuscular mycorrhizal infectivity of sandy soils in the south-western Cape, South Africa. S. Afr. J. Bot. 1989, 55, 310-313. [CrossRef]

43. Allsopp, N.; Stock, W.D. VA Mycorrhizal Infection in Relation to Edaphic Characteristics and Disturbance Regime in Three Lowland Plant Communities in the South-Western Cape, South Africa. J. Ecol. 1994, 82, 271-279. [CrossRef]

44. Brundrett, M.C. Coevolution of roots and mycorrhizas of land plants. New Phytol. 2002, 154, $275-304$. [CrossRef]

45. Cloete, K.J.; Valentine, A.J.; Blomerus, L.M.; Botha, A.; Pèrez-Fernández, M.A. Nutritional effects of indigenous arbuscular mycorrhizal associations on the sclerophyllous species Agathosma betulina. Web Ecol. 2007, 7, 77-86. [CrossRef]

46. Allsopp, N.; Stock, W.D. Density dependent interactions between VA mycorrhizal fungi and even-aged seedlings of two perennial Fabaceae species. Oecologia 1992, 91, 281-287. [CrossRef]

47. Slabbert, E. Microbial Communities of Riparian Ecotone Invaded by Non-Indigenous Acacias; Stellenbosch University: Stellenbosch, South Africa, 2012. 
48. Allsopp, N.; Holmes, P.M. The impact of alien plant invasion on mycorrhizas in mountain fynbos vegetation. S. Afr. J. Bot. 2001, 67, 150-156. [CrossRef]

49. Malloch, D.W.; Pirozynski, K.A.; Raven, P.H. Ecological and evolutionary significance of mycorrhizal symbioses in vascular plants (A Review). Proc. Natl. Acad. Sci. USA 1980, 77, 2113-2118. [CrossRef]

50. Robinson, R.K. Mycorrhiza in certain Ericaceae native to southern Africa. J. S. Afr. Bot. 1973, 39, $123-129$.

51. Pirie, M.D.; Oliver, E.G.H.; Bellstedt, D.U. A densely sampled ITS phylogeny of the Cape flagship genus Erica L. suggests numerous shifts in floral macro-morphology. Mol. Phylogenet. Evol. 2011, 61, 593-601. [CrossRef]

52. Schwery, O.; Onstein, R.E.; Bouchenak-Khelladi, Y.; Xing, Y.; Carter, R.J.; Linder, H.P. As old as the mountains: The radiations of the Ericaceae. New Phytol. 2015, 207, 355-367. [CrossRef]

53. Straker, C.J.; Mitchell, D.T. The characterization and estimation of polyphosphates in endomycorrhizas of the Ericaceae. New Phytol. 1985, 99, 431-440. [CrossRef]

54. Straker, C.J.; Mitchell, D.T. The Activity and Characterization of Acid Phosphatases in Endomycorrhizal Fungi of the Ericaceae. New Phytol. 1986, 104, 243-256. [CrossRef]

55. Straker, C.J.; Mitchell, D.T. Kinetic Characterization of a Dual Phosphate Uptake System in the Endomycorrhizal Fungus of Erica hispidula L. New Phytol. 1987, 106, 129-137. [CrossRef]

56. Straker, C.J.; Gianinazzi-Pearson, V.; Gianinazzi, S.; Cleyet-Marel, J.-C.; Bousquet, N. Electrophoretic and immunological studies on acid phosphatase from a mycorrhizal fungus of Erica hispidula L. New Phytol. 1989, 111, 215-221. [CrossRef]

57. Read, D.J. The structure and function of the ericoid mycorrhizal root. Ann. Bot. 1996, 77, 365-374. [CrossRef]

58. Cairney, J.W.G.; Ashford, A.E. Biology of mycorrhizal associations of epacrids (Ericaceae). New Phytol. 2002, 154, 305-326. [CrossRef]

59. Vohník, M.; Albrechtová, J. The Co-occurrence and Morphological Continuum Between Ericoid Mycorrhiza and Dark Septate Endophytes in Roots of Six European Rhododendron Species. Folia Geobot. 2011, 46, 373-386. [CrossRef]

60. Straker, C.J. Ericoid mycorrhiza: Ecological and host specificity. Mycorrhiza 1996, 6, 215-225. [CrossRef]

61. Bruzone, M.C.; Fontenla, S.B.; Vohník, M. Is the prominent ericoid mycorrhizal fungus Rhizoscyphus ericae absent in the Southern Hemisphere's Ericaceae? A case study on the diversity of root mycobionts in Gaultheria spp. from northwest Patagonia, Argentina. Mycorrhiza 2015, 25, 25-40. [CrossRef]

62. Smith, S.; Read, D.J. Mycorrhizal Symbiosis, 3rd ed.; Academic Press: London, UK, 2008; ISBN 978-0-12-370526-6.

63. Pearson, V.; Read, D.J. The Biology of Mycorrhiza in the Ericaceae. II. The Transport of Carbon and Phosphorus by the Endophyte and the Mycorrhiza. New Phytol. 1973, 72, 1325-1331. [CrossRef]

64. Crous, P.W.; Rong, I.H.; Wood, A.; Lee, S.; Glen, H.; Botha, W.; Slippers, B.; De Beer, W.Z.; Wingfield, M.J.; Hawksworth, D.L. How many species of fungi are there at the tip of Africa? Stud. Mycol. 2006, 55, 13-33. [CrossRef]

65. Van Wyk, P.S.; Marasas, W.F.O.; Knox-Davies, P.S. Batcheloromyces leucadendri sp. nov. on Leucadendron spp. in South Africa. S. Afr. J. Bot. 1985, 51, 344-346. [CrossRef]

66. Crous, P.W. New and interesting records of South African fungi. XIII. Foliicolous microfungi. S. Afr. J. Bot. 1993, 59, 602-610. [CrossRef]

67. Lee, S.; Crous, P.W.; Wingfield, M.J. Pestalotioid fungi from Restionaceae in the Cape Floral Kingdom. Stud. Mycol. 2006, 55, 175-187. [CrossRef]

68. Swart, L.; Crous, P.W.; Denman, S.; Palm, M.E. Fungi occurring on Proteaceae. I. S. Afr. J. Bot. 1998, 64, 137-145. [CrossRef]

69. Marais, G.J.; Wingfield, M.J. Fungi associated with infructescences of Protea species in South Africa, including a new species of Ophiostoma. Mycol. Res. 1994, 98, 369-374. [CrossRef]

70. Marais, G.J.; Wingfield, M.J. Ophiostoma protearum sp. nov. associated with Protea caffra infructescences. Can. J. Bot. 1997, 75, 362-367. [CrossRef]

71. Lee, S.; Crous, P.W. New species of Anthostomella on fynbos, with a key to the genus in South Africa. Mycol. Res. 2003, 107, 360-370. [CrossRef]

72. Lee, S.; Crous, P.W. New coelomycetes occurring on Restionaceae. Sydowia 2003, 55, 115-128.

73. Lee, S.; Groenewald, J.Z.; Taylor, J.E.; Roets, F.; Crous, P.W. Rhynchostomatoid fungi occurring on Proteaceae. Mycologia 2003, 95, 902-910. [CrossRef] 
74. Van Wyk, P.S.; Marasas, W.F.O.; Knox-Davies, P.S. Ascomycetous leaf pathogens of Protea, Leucadendron and Leucospermum in South Africa. Phytophylactica 1975, 7, 91-94.

75. Knox-Davies, P.S.; van Wyk, P.S.; Marasas, W.F.O. Diseases of Protea, Leucospermum and Leucadendron recorded in South Africa. Phytophylactica 1987, 19, 327-337.

76. Orffer, S.; Pathology, P. A canker and die-back disease of Protea repens. Phytophylactica 1989, 21, $189-194$.

77. Crous, P.W.; Wingfield, M.J. Additions to Mycosphaerella in the fynbos biome. Mycotaxon 1993, 46, $19-26$.

78. Taylor, J.E.; Denman, S.; Crous, P.W. Endophytes isolated from three species of Protea in a nature reserve in the Western Cape, South Africa. Sydowia 2001, 53, 247-260.

79. Taylor, J.E.; Crous, P.W. Phaeophleosporafaureae comb. novo associated with leaf spots on Faurea saligna (Proteaceae), with a key to the species of Phaeophleospora. Fungal Divers. 1999, 3, 153-158.

80. Mostert, L.; Kang, J.; Crous, P.W.; Denman, S. Phomopsis saccharata sp.nov., causing a canker and die-back disease of Protea repens in South Africa. Sydowia 2001, 53, 227-235.

81. Taylor, J.E.; Lee, S.; Crous, P.W. Biodiversity in the Cape Floral Kingdom: Fungi occurring on Proteaceae. Mycol. Res. 2001, 105, 1480-1484. [CrossRef]

82. Visagie, C.M.; Houbraken, J.; Rodriques, C.; Silva Pereira, C.; Dijksterhuis, J.; Seifert, K.A.; Jacobs, K.; Samson, R.A. Five new Penicillium species in section sclerotiora: A tribute to the Dutch Royal family. Persoonia 2013, 31, 42-62. [CrossRef] [PubMed]

83. Yilmaz, N.; Lopez-Quintero, C.A.; Vasco-Palacios, A.M.; Frisvad, J.C.; Theelen, B.; Boekhout, T.; Samson, R.A.; Houbraken, J. Four novel Talaromyces species isolated from leaf litter from Colombian Amazon rain forests. Mycol. Prog. 2016, 15, 1041-1056. [CrossRef]

84. Roets, F.; Dreyer, L.L.; Crous, P.W. Seasonal trends in colonisation of Protea infructescences by Gondwanamyces and Ophiostoma spp. S. Afr. J. Bot. 2005, 71, 307-311. [CrossRef]

85. Allsopp, N.; Olivier, D.L.; Mitchell, D.T. Fungal populations associated with root systems of proteaceous seedlings at a lowland fynbos site in South Africa. S. Afr. J. Bot. 1987, 53, 365-369. [CrossRef]

86. Postma, A. Soil Microbial Communities Associated with two Commercially Important Plant Species Indigenous to the Fynbos Region of South Africa: Cyclopia spp. (honeybush) and Aspalathus linearis (rooibos); Stellenbosch University: Stellenbosch, South Africa, 2016.

87. Cloete, K.J.; Valentine, A.J.; Stander, M.A.; Blomerus, L.M.; Botha, A. Evidence of symbiosis between the soil yeast Cryptococcus laurentii and a sclerophyllous medicinal shrub, Agathosma betulina (Berg.) Pillans. Microb. Ecol. 2009, 57, 624-632. [CrossRef]

88. Vreulink, J.M.; Esterhuyse, A.; Jacobs, K.; Botha, A. Soil properties that impact yeast and actinomycete numbers in sandy low nutrient soils. Can. J. Microbiol. 2007, 53, 1369-1374. [CrossRef]

89. Barnard, R.L.; Osborne, C.A.; Firestone, M.K. Changing precipitation pattern alters soil microbial community response to wet-up under a Mediterranean-type climate. ISME J. 2015, 9, 946-957. [CrossRef]

90. Lawal, S.; Lennard, C.; Hewitson, B. Response of southern African vegetation to climate change at 1.5 and $2.0^{\circ}$ global warming above the pre-industrial level. Clim. Serv. 2019, 16, 100134. [CrossRef]

91. Lemaire, B.; Van Cauwenberghe, J.; Verstraete, B.; Chimphango, S.; Stirton, C.; Honnay, O.; Smets, E.; Sprent, J.; James, E.K.; Muasya, A.M. Characterization of the papilionoid-Burkholderia interaction in the Fynbos biome: The diversity and distribution of beta-rhizobia nodulating Podalyria calyptrata (Fabaceae, Podalyrieae). Syst. Appl. Microbiol. 2016, 39, 41-48. [CrossRef] [PubMed]

92. Magadlela, A.; Vardien, W.; Kleinert, A.; Dreyer, L.L.; Valentine, A.J. The role of phosphorus deficiency in nodule microbial composition, and carbon and nitrogen nutrition of a native legume tree in the Cape fynbos ecosystem. Aust. J. Bot. 2015, 63, 379-386. [CrossRef]

93. Beukes, C.W.; Steenkamp, E.T.; van Zyl, E.; Avontuur, J.; Chan, W.Y.; Hassen, A.I.; Palmer, M.; Mthombeni, L.S.; Phalane, F.L.; Sereme, T.K.; et al. Paraburkholderia strydomiana sp. nov. and Paraburkholderia steynii sp. nov.: Rhizobial symbionts of the fynbos legume Hypocalyptus sophoroides. Antonie Van Leeuwenhoek 2019, 112, 1369-1385. [CrossRef]

94. Kanu, S.A.; Dakora, F.D. Symbiotic nitrogen contribution and biodiversity of root-nodule bacteria nodulating Psoralea species in the Cape Fynbos, South Africa. Soil Biol. Biochem. 2012, 54, 68-76. [CrossRef]

95. Lemaire, B.; Chimphango, S.B.M.; Stirton, C.; Rafudeen, S.; Honnay, O.; Smets, E.; Chen, W. Biogeographical Patterns of Legume-Nodulating Burkholderia spp.: From African Fynbos to Continental Scales. Appl. Environ. Microbiol. 2016, 82, 5099-5115. [CrossRef] 
96. Howieson, J.G.; De Meyer, S.E.; Vivas-Marfisi, A.; Ratnayake, S.; Ardley, J.K.; Yates, R.J. Novel Burkholderia bacteria isolated from Lebeckia ambigua-A perennial suffrutescent legume of the fynbos. Soil Biol. Biochem. 2013, 60, 55-64. [CrossRef]

97. Felix, D. Dakora Root-nodule bacteria isolated from native Amphithalea ericifolia and four indigenous Aspalathus species from the acidic soils of the South African fynbos are tolerant to very low $\mathrm{pH}$. Afr. J. Biotechnol. 2012, 11, 3766-3772.

98. Human, Z.R.; Crous, C.J.; Roets, F.; Venter, S.N.; Wingfield, M.J.; de Beer, Z.W. Biodiversity and ecology of flower-associated actinomycetes in different flowering stages of Protea repens. Antonie Van Leeuwenhoek 2018, 111, 209-226. [CrossRef]

99. Barns, S.M.; Takala, S.L.; Kuske, C.R. Wide Distribution and Diversity of Members of the Bacterial Kingdom Acidobacterium in the Environment. Appl. Environ. Microbiol. 1999, 65, 1731-1737. [CrossRef]

100. Janssen, P.H. Identifying the Dominant Soil Bacterial Taxa in Libraries of 16S rRNA and 16S rRNA Genes. Appl. Environ. Microbiol. 2006, 72, 1719-1728. [CrossRef]

101. Dedysh, S.N.; Damsté, J.S.S. Acidobacteria. In eLS; John Wiley \& Sons Ltd: Chichester, UK, 2018. [CrossRef]

102. Eichorst, S.A.; Trojan, D.; Roux, S.; Herbold, C.; Rattei, T.; Woebken, D. Genomic insights into the Acidobacteria reveal strategies for their success in terrestrial environments. Environ. Microbiol. 2018, 20, 1041-1063. [CrossRef]

103. Miyambo, T.; Makhalanyane, T.P.; Cowan, D.A.; Valverde, A. Plants of the fynbos biome harbour host species-specific bacterial communities. FEMS Microbiol. Lett. 2016, 363, 1-8. [CrossRef]

104. Moroenyane, I.; Chimphango, S.B.M.; Dong, K.; Tripathi, B.; Singh, D.; Adams, J.M. Neutral models predict biogeographical patterns of soil microbes at a local scale in Mediterranean heathlands, South Africa. Trans. R. Soc. South Africa 2019, 74, 139-150. [CrossRef]

105. Dedysh, S.N.; Yilmaz, P. Refining the taxonomic structure of the phylum Acidobacteria. Int. J. Syst. Evol. Microbiol. 2018, 68, 3796-3806. [CrossRef]

106. Stafford, W.H.L.; Baker, G.C.; Brown, S.A.; Burton, S.G.; Cowan, D.A. Bacterial diversity in the rhizosphere of Proteaceae species. Environ. Microbiol. 2005, 7, 1755-1768. [CrossRef]

107. Crits-Christoph, A.; Diamond, S.; Butterfield, C.N.; Thomas, B.C.; Banfield, J.F. Novel soil bacteria possess diverse genes for secondary metabolite biosynthesis. Nature 2018, 558, 440-444. [CrossRef]

108. Diamond, S.; Andeer, P.F.; Li, Z.; Crits-Christoph, A.; Burstein, D.; Anantharaman, K.; Lane, K.R.; Thomas, B.C.; Pan, C.; Northen, T.R.; et al. Mediterranean grassland soil C-N compound turnover is dependent on rainfall and depth, and is mediated by genomically divergent microorganisms. Nat. Microbiol. 2019, 4, 1356-1367. [CrossRef]

109. Kielak, A.M.; Barreto, C.C.; Kowalchuk, G.A.; van Veen, J.A.; Kuramae, E.E. The ecology of Acidobacteria: Moving beyond genes and genomes. Front. Microbiol. 2016, 7, 744. [CrossRef]

110. Segobola, J.; Adriaenssens, E.; Tsekoa, T.; Rashamuse, K.; Cowan, D. Exploring Viral Diversity in a Unique South African Soil Habitat. Sci. Rep. 2018, 8, 111. [CrossRef]

111. Emerson, J.B. Soil Viruses: A New Hope. mSystems 2019, 4, 1-4. [CrossRef]

112. Trubl, G.; Jang, H.B.; Roux, S.; Emerson, J.B.; Solonenko, N.; Vik, D.R.; Solden, L.; Ellenbogen, J.; Runyon, A.T.; Bolduc, B.; et al. Soil Viruses Are Underexplored Players in Ecosystem Carbon Processing. mSystems 2018, 3, 1-21. [CrossRef]

113. Marais, C.; Wannenburgh, A.M. Restoration of water resources (natural capital) through the clearing of invasive alien plants from riparian areas in South Africa-Costs and water benefits. S. Afr. J. Bot. 2008, 74, 526-537. [CrossRef]

114. Prins, N.; Holmes, P.M.; Richardson, D.M. A reference framework for the restoration of riparian vegetation in the Western Cape, South Africa, degraded by invasive Australian Acacias. S. Afr. J. Bot. 2004, 70, 767-776. [CrossRef]

115. Van Wilgen, B.W.; Wilson, J.R.; Wannenburgh, A.; Foxcroft, L.C. The Extent and Effectiveness of Alien Plant Control Projects in South Africa. In Biological Invasions in South Africa; Springer: Cham, Switzerland, 2020; pp. 597-628, ISBN 978-3-030-32394-3.

116. Van Wilgen, B.W.; Measey, J.; Richardson, D.M.; Wilson, J.R.; Zengeya, T.A. Biological Invasions in South Africa; Springer: Cham, Switzerland, 2020; ISBN 978-3-030-32393-6.

117. Morris, T.L.; Esler, K.J.; Barger, N.N.; Jacobs, S.M.; Cramer, M.D. Ecophysiological traits associated with the competitive ability of invasive Australian Acacias. Divers. Distrib. 2011, 17, 898-910. [CrossRef] 
118. Tererai, F.; Gaertner, M.; Jacobs, S.M.; Richardson, D.M. Eucalyptus invasions in riparian forests: Effects on native vegetation community diversity, stand structure and composition. For. Ecol. Manag. 2013, 297, 84-93. [CrossRef]

119. Crous, C.J.; Jacobs, S.M.; Esler, K.J. Drought-tolerance of an invasive alien tree, Acacia mearnsii and two native competitors in fynbos riparian ecotones. Biol. Invasions 2012, 14, 619-631. [CrossRef]

120. Gaertner, M.; Breeyen, A.D.; Hui, C.; Richardson, D.M. Impacts of alien plant invasions on species richness in mediterranean-type ecosystems: A meta-analysis. Prog. Phys. Geogr. 2009, 33, 319-338. [CrossRef]

121. Henderson, L. Invasive, naturalized and casual alien plants in southern Africa: A summary based on the Southern African Plant Invaders Atlas (SAPIA). Bothalia 2007, 37, 215-248. [CrossRef]

122. Constantinides, M.; Fownes, J.H. Nitrogen Mineralization from Leaves and Litter of Tropical Plants: Relationship to Nitrogen, Lignin and Soluble Polyphenol Concentrations. Soil Biol. Biochem. 1994, 26, 49-55. [CrossRef]

123. Zhang, H.; Guan, D.S.; Song, M.W. Biomass and carbon storage of Eucalyptus and Acacia plantations in the Pearl River Delta, South China. For. Ecol. Manag. 2012, 277, 90-97. [CrossRef]

124. Le Maitre, D.C.; Gaertner, M.; Marchante, E.; Ens, E.J.; Holmes, P.M.; Pauchard, A.; O'Farrell, P.J.; Rogers, A.M.; Blanchard, R.; Blignaut, J.; et al. Impacts of invasive Australian acacias: Implications for management and restoration. Divers. Distrib. 2011, 17, 1015-1029. [CrossRef]

125. Lazzaro, L.; Giuliani, C.; Fabiani, A.; Agnelli, A.E.; Pastorelli, R.; Lagomarsino, A.; Benesperi, R.; Calamassi, R.; Foggi, B. Soil and plant changing after invasion: The case of Acacia dealbata in a Mediterranean ecosystem. Sci. Total Environ. 2014, 497-498, 491-498. [CrossRef] [PubMed]

126. Yelenik, S.G.; Stock, W.D.; Richardson, D.M. Functional group identity does not predict invader impacts: Differential effects of nitrogen-fixing exotic plants on ecosystem function. Biol. Invasions 2007, 9, 117-125. [CrossRef]

127. Tye, D.R.C.; Drake, D.C. An exotic Australian Acacia fixes more N than a coexisting indigenous Acacia in a South African riparian zone. Plant Ecol. 2012, 213, 251-257. [CrossRef]

128. Simaika, J.P.; Jacobs, S.; Railoun, Z.; Wiener, K. Towards the Development of a Tool to Quantify and Monitor Stream Restoration Success Following Removal of Riparian Invasive Alien Plants; Water Research Commission: Pretoria, South Africa, 2018; ISBN 978-0-6392-0038-5.

129. Werner, C.; Peperkorn, R.; Máguas, C.; Beyschlag, W. Competitive balance between the alien invasive Acacia longifolia and native Mediterranean species. In Plant Invasions: Human Perception, Ecological Impacts and Management; Tokarska-Guzik, B., Brock, J., Brundu, G., Child, L., Daehler, C., Pysek, P., Eds.; Backhuys Publishers: Leiden, The Netherlands, 2008; pp. 261-275, ISBN 978-3-8236-1528-6.

130. Yelenik, S.G.; Richardson, W.D.; Stock, D.M. Ecosystem Level Impacts of Invasive Acacia saligna in the South African Fynbos. Restor. Ecol. 2004, 12, 44-51. [CrossRef]

131. Badalamenti, E.; Gristina, L.; Laudicina, V.A.; Novara, A.; Pasta, S.; La Mantia, T. The impact of Carpobrotus cfr. acinaciformis (L.) L. Bolus on soil nutrients, microbial communities structure and native plant communities in Mediterranean ecosystems. Plant Soil 2016, 409, 19-34. [CrossRef]

132. Tererai, F.; Gaertner, M.; Jacobs, S.M.; Richardson, D.M. Resilience of Invaded Riparian Landscapes: The Potential Role of Soil-Stored Seed Banks. Environ. Manag. 2015, 55, 86-99. [CrossRef]

133. Kerr, T.F.; Ruwanza, S. Does Eucalyptus grandis invasion and removal affect soils and vegetation in the Eastern Cape Province, South Africa? Austral. Ecol. 2016, 41, 328-338. [CrossRef]

134. Nsikani, M.M.; Novoa, A.; van Wilgen, B.W.; Keet, J.H.; Gaertner, M. Acacia saligna's soil legacy effects persist up to 10 years after clearing: Implications for ecological restoration. Austral Ecol. 2017, 42, 880-889. [CrossRef]

135. Witkowski, W.T.F.; Mitchell, D.T. Variations in Soil Phosphorus in the Fynbos Biome, South Africa. J. Ecol. 1987, 75, 1159-1171. [CrossRef]

136. Witkowski, W.T.F. Effects of Invasive Alien Acacias on Nutrient Cycling in the Coastal Lowlands of the Cape Fynbos. J. Appl. Ecol. 1991, 28,1-15. [CrossRef]

137. Ruwanza, S.; Gaertner, M.; Richardson, D.M.; Esler, K.J. Soil water repellency in riparian systems invaded by Eucalyptus camaldulensis: A restoration perspective from the Western Cape Province, South Africa. Geoderma 2013, 200-201, 9-17. [CrossRef] 
138. Jacobs, S.; Cogill, L.; Jacobs, K.; Juba, R.; Maubane, T.; Slabbert, E.; Smart, R. Determining the Biomass and Nutrient Content of Invasive Acacia mearnsii and Eucalyptus camaldulensis Trees in Fynbos Riparian Zones; Water Research Commission: Pretoria, South Africa, 2017; ISBN 978-1-4312-0890-6.

139. Ruwanza, S.; Gaertner, M.; Esler, K.J.; Richardson, D.M. Allelopathic effects of invasive Eucalyptus camaldulensis on germination and early growth of four native species in the Western Cape, South Africa. South. For. 2015, 77, 91-105. [CrossRef]

140. Richardson, D.M.; Allsopp, N.; D’Antonio, C.M.; Milton, S.J.; Rejmánek, M. Plant invasions-The role of mutualisms. Biol. Rev. 2000, 75, 65-93. [CrossRef]

141. Ravichandran, K.R.; Thangavelu, M. Role and influence of soil microbial communities on plant invasion. Ecol. Quest. 2017, 27, 9-23. [CrossRef]

142. Le Roux, J.J.; Clusella-Trullas, S.; Mokotjomela, T.M.; Mairal, M.; Richardson, D.M.; Skein, L.; Wilson, J.R.; Weyl, O.L.F.; Geerts, S. Biotic Interactions as Mediators of Biological Invasions: Insights from South Africa. In Biological Invasions in South Africa; Springer: Cham, Switzerland, 2020; ISBN 9783030323943.

143. Jacobsen, A.L.; Roets, F.; Jacobs, S.M.; Esler, K.J.; Pratt, R. Dieback and mortality of South African fynbos shrubs is likely driven by a novel pathogen and pathogen-induced hydraulic failure. Austral Ecol. 2012, 37, 227-235. [CrossRef]

144. Stępkowski, T.; Moulin, L.; Krzyżańska, A.; McInnes, A.; Law, I.J.; Howieson, J. European Origin of Bradyrhizobium Populations Infecting Lupins and Serradella in Soils of Western Australia and South Africa. Appl. Environ. Microbiol. 2005, 71, 501-519. [CrossRef]

145. Warrington, S.; Ellis, A.; Novoa, A.; Wandrag, E.M.; Hulme, P.E.; Duncan, R.P.; Valentine, A.; Le Roux, J.J. Cointroductions of Australian acacias and their rhizobial mutualists in the Southern Hemisphere. J. Biogeogr. 2019, 46, 1519-1531. [CrossRef]

146. Rodríguez-Echeverría, S.; Le Roux, J.J.; Crisóstomo, J.A.; Ndlovu, J. Jack-of-all-trades and master of many? How does associated rhizobial diversity influence the colonization success of Australian Acacia species? Divers. Distrib. 2011, 17, 946-957. [CrossRef]

147. Jairus, T.; Mpumba, R.; Chinoya, S.; Tedersoo, L. Invasion potential and host shifts of Australian and African ectomycorrhizal fungi in mixed eucalypt plantations. New Phytol. 2011, 192, 179-187. [CrossRef]

148. Hurley, B.P.; Slippers, B.; Wingfield, M.J. A comparison of control results for the alien invasive woodwasp, Sirex noctilio, in the southern hemisphere. Agric. For. Entomol. 2007, 9, 159-171. [CrossRef]

149. Wood, A.R.; Morris, M.J. Impact of the gall-forming rust fungus Uromycladium tepperianum on the invasive tree Acacia saligna in South Africa: 15 years of monitoring. Biol. Control 2007, 41, 68-77. [CrossRef]

150. Smart, R. The Effect of Fire Scars on Microbial Diversity of Fynbos Soil; Stellenbosch University: Stellenbosch, South Africa, 2017.

151. Nsikani, M.M.; van Wilgen, B.W.; Bacher, S.; Gaertner, M. Re-establishment of Protea repens after clearing invasive Acacia saligna: Consequences of soil legacy effects and a native nitrophilic weedy species. S. Afr. J. Bot. 2018, 116, 103-109. [CrossRef]

152. Nsikani, M.M.; Gaertner, M.; Kritzinger-Klopper, S.; Ngubane, N.P.; Esler, K.J. Secondary invasion after clearing invasive Acacia saligna in the South African fynbos. S. Afr. J. Bot. 2019, 125, 280-289. [CrossRef]

(C) 2020 by the authors. Licensee MDPI, Basel, Switzerland. This article is an open access article distributed under the terms and conditions of the Creative Commons Attribution (CC BY) license (http://creativecommons.org/licenses/by/4.0/). 